\title{
The Chemistry in Re-Frying of Foods
}

\section{Parul Thapar*}

Assistant Professor, Guru Nanak Institute of Technology (Mullana), Ambala, Haryana, India

*Corresponding Author: Parul Thapar, Assistant Professor, Guru Nanak Institute of Technology (Mullana), Ambala, Haryana, India.

Received: April 09, 2019; Published: May 16, 2019

DOI: $10.31080 /$ ASPS.2019.03.0284

\begin{abstract}
Frying is a process of immersing food in hot oil at a high temperature of $150^{\circ} \mathrm{C}-190^{\circ} \mathrm{C}$. On the other hand, re-frying is repeated use of left-over frying oil which has already been consumed for frying a particular food. There are various chemical reactions involved during frying and re-frying of foods which generates some hazardous chemical compounds which are not beneficial for health. Therefore, in this review paper, drawbacks of re-frying of oil during preparation of fried food has been explained. Also, if re-fried food has been consumed in excess amounts, there are some precautions mentioned in the paper which can be followed.
\end{abstract}

Keywords: Chemical Reactions; Hazardous Compounds; Frying and Re-Frying

\section{Introduction}

Frying is a process of immersing food in hot oil at a high temperature of $150^{\circ} \mathrm{C}-190^{\circ} \mathrm{C}$. There is a simultaneous heat and mass transfer of oil, food and air during frying which produces desirable and unique quality of fried foods with good texture and flavour. On the other hand, re-frying is repeated use of left-over frying oil which has already been consumed for frying a particular food.

\section{Composition of oils}

Oils are fats which are liquid at room temperature. Oils belong to a group of biological substances called lipids. Lipids are biological chemicals that do not dissolve in water [1].

Function of lipids [1,2]:

- $\quad$ Act as regulatory messangers (hormones).

- Forms the basis for structural components of cell membranes.

- $\quad$ Act as store- house of energy.

- Insulate body organs.

- Transport fat- soluble vitamins through blood.

Molecular structure of oils- Oils are composed of three fatty acids and a glycerol molecule [1] and is shown in Figure 1.
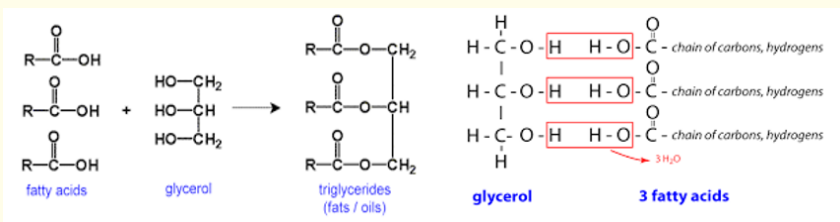

Figure 1: Molecular structure of oils.

Thus, these fats are also called tri-glycerides or tri-acyl glycerol. When, the fatty acids contain single bond in between each C- atom, then the fats are called saturated fats and when $\mathrm{C}$-atoms are bonded by certain double bonds in a chain of fatty acid molecule, then the fats are called unsaturated fats. If, in a carbon chain, one double bond is present, then the oil is said to be mono-unsaturated and if in a carbon-chain, more than one double bond is present, then the oil is said to be poly-unsaturated [1].

Kinds of oils used for frying food

The types of oil used for cooking and the percent of total fatty acids present are shown in Table 1 below [3].

\section{Chemical changes in oil during frying}

When the frying takes place, the following changes occur in the composition of oil 
Hydrolysis of oil- Hydrolysis means breakdown of oil into free fatty acids and glycerol. This process increases with increase in frying.4 Permissible free fatty acid content in oil- Max- $0.08 \%-1.00 \%$ [5].

- $\quad$ Oxidation of oil- When the fried oil (frying temperature) comes in contact with oxygen in air, it gives rancid flavor. The rancid flavor is because of the reaction of free fatty acid in the oil with oxygen, which is known as oxidative rancidity. This reaction produces various compounds like including aldehydes, ketones or other volatile products like sterol oxides. These products are responsible for rancid odours and flavours [6].

\begin{tabular}{|c|c|c|c|c|}
\hline \multirow[b]{2}{*}{ S. No. } & \multirow[b]{2}{*}{ Kinds of oil } & \multicolumn{3}{|c|}{ Percent of total fatty acids } \\
\hline & & $\begin{array}{l}\text { Satu- } \\
\text { rated }\end{array}$ & $\begin{array}{c}\text { Mono- } \\
\text { unsaturated }\end{array}$ & $\begin{array}{c}\text { Poly- } \\
\text { unsaturated }\end{array}$ \\
\hline 1. & Safflower oil & 9 & 12 & 75 \\
\hline 2. & Sunflower oil & 10 & 20 & 66 \\
\hline 3. & Corn oil & 13 & 24 & 59 \\
\hline 4. & Olive oil & 13 & 74 & 8 \\
\hline 5. & Soybean oil & 14 & 23 & 58 \\
\hline 6. & Peanut oil & 17 & 46 & 32 \\
\hline 8. & $\begin{array}{c}\text { Cotton seed } \\
\text { oil }\end{array}$ & 26 & 18 & 52 \\
\hline 9. & Lard & 40 & 45 & 11 \\
\hline 10. & Palm-oil & 49 & 37 & 9 \\
\hline 11. & $\begin{array}{c}\text { Palm-kernel } \\
\text { oil }\end{array}$ & 81 & 11 & 2 \\
\hline 12. & Coconut oil & 86 & 6 & 2 \\
\hline
\end{tabular}

Table 1: Percentage of total fatty acids in cooking oil.

Oil (During frying) + Oxygen (Air) $\rightarrow$ dehydes, Ketones

Frying temperature (Rancid flavor)

Polymerization of oil- Frying of oil, leads to decomposition of oil with generation of products like dimers and non- polar polymers, cyclic monomers, trans isomers and position isomers [6].

Polymers are acyclic or cyclic compounds depending on the kinds of fatty acids forming an oil. The acyclic polymers are formed when fatty acids like oleic acid are present in oil. Also, oils rich in linoleic acid is more easily polymerized than oleic acid [6]. Linoleic acid content of various oils is presented in Table 2 .

\begin{tabular}{|c|c|c|}
\hline S. No. & Name & Linoleic acid (\%) ${ }^{\dagger}$ \\
\hline 1. & Safflower oil & 78 \\
\hline 2 & Grape-seed oil & 73 \\
\hline 3 & Poppy seed oil & 70 \\
\hline 4 & Sunflower oil & 68 \\
\hline 5 & Hemp oil & 60 \\
\hline 6 & Corn oil & 59 \\
\hline 7 & Wheatgerm oil & 55 \\
\hline 8 & Cotton seed oil & 54 \\
\hline 9 & Soybean oil & 51 \\
\hline 10 & Walnut oil & 51 \\
\hline 11 & Sesame oil & 45 \\
\hline 12 & Rice bran oil & 39 \\
\hline 13 & Peanut oil & 32 \\
\hline 15 & Canola oil & 21 \\
\hline 16 & Egg Yolk & 16 \\
\hline 17 & Linseed oil & 15 \\
\hline 18 & Lard & 10 \\
\hline 19 & Olive oil & 10 \\
\hline 20 & Palm oil & 10 \\
\hline 21 & Butter & 2 \\
\hline 22 & Coconut oil & 2 \\
\hline${ }^{\dagger}$ Average value & & \\
\hline
\end{tabular}

Table 2: Percentage of linoleic acid in oils.

Flavour Quality of frying oil- During frying, certain compounds are formed from linoleic acid. Volatile compounds like dienals, alkenals, lactones, hydrocarbons and various cyclic compounds produces off- odours and flavours. Hence, sensory quality of the fried food decreases [6].

Changes in nutrients in food- As mentioned above, during oxidation of oil, the aldehydes and ketones which are formed, react with amines, amino acids and proteins in fried foods. This causes nutrient loss and browning in fried foods [6].

The overall changes in the composition of food is mentioned below in Table 3 [6].

\section{Ill- Effects of re-frying of oil}

Once the oil has been utilized for frying in a batch, and the remaining oil when kept for longer time without any use, to be used again, has certain disadvantages which should be noted; 
- Increase in fatty acid content- As seen above, hydrolysis of oil leads to development of free fatty acid content which increases with re-frying of oil. If an oil has free fatty acid content greater than the permissible limit, then the oil becomes unsuitable to be used, since free fatty acids are insoluble in water and they have tendency to get maximum oxidized [6].

- Increase in rancidity- Free fatty acids and their oxidized compounds produce rancid (off- flavors) and makes the oil less acceptable for re-frying.Rancidity leads to loss of freshness in food, affects the shelf- life of food adds an objectionable flavours and odours [7]. Increased rancidity due to re-frying of oil produces certain toxic compounds like acrylamide which is a probable human carcinogen [6].

- Increase in polymerization- With re-frying, the polymerization of oil increases, which accelerates the degradation of oil, which increases oil viscocity, reduces heat transfer, produce foam during frying and develops undesirable colour in food. Polymers also cause high oil absorption in foods [6].

- Generation of toxic compounds- With re-frying, certain cyclic compounds are formed from linoleic acid like 1,4- dioxane, benzene, toluene and hexyl benzene which do not contribute to desirable flavor and are toxic in nature. Re-frying also increases the formation of trans-fatty acids (depending on oil used). These trans-fatty acids cause the risk of cardiovascular diseases [6].

- $\quad$ Nutrient loss in fried foods- When the oil is used for re- frying, the intensity of browning of food increases which also leads to loss of essential amino acids like lysine in fried food. There is also loss of vitamins like Vitamin C (ascorbic acid), Vitamin B (thiamine, riboflavin, niacin and B6), Vitamin $A$ and Vitamin $E$ which changes the favour and colour of oil.6 Due to the destruction of these nutrients, adverse health effects could occur like mutations or gastro-intestinal irritations [7].

\begin{tabular}{|l|l|}
\hline Component & \multicolumn{1}{|c|}{ Changes during frying } \\
\hline Fat & $\begin{array}{l}\text { Increased concentration and change in compo- } \\
\text { sition }\end{array}$ \\
\hline Water & Significant loss \\
\hline Sugars & Browning \\
\hline Proteins & Alteration of the composition \\
\hline Amino acids & Formation of undesirable flavouring substances \\
\hline Vitamins & Moderate loss \\
\hline Minerals & Small loss \\
\hline Antioxidants & Moderate loss \\
\hline
\end{tabular}

Table 3: Changes in composition of food during frying.

\section{Conclusion}

Fried foods are the major attractions for each and every person. Everyone like to have some or the other kind of fried food for a mouth change. But, there are certain drawbacks which should be avoided before consuming a fried food, as mentioned above. It is obvious that the hawkers on streets have to look at their economy and save the oil for re-use. Thus, in that case, it is our duty to consume those foods in limited quantity. At homes, after preparation of a batch of food, it should be kept in mind that the remaining oil has to be discarded and not kept for re-frying. If possible, the left-over oil should be collected and sent to an oil-refinery which utilizes the cooking oil for re-cycling. In this way, the left- over oil will not be wasted and also help oil- refineries, which is a kind of contribution in oil industry. Also, the oils which are rich in high percent of linoleic acid can be avoided. Some oils have "smoke point" at a specific temperature. "Smoke point" is the point at which oils begin to break- down and can have a foul odour or taste. Therefore, the oils which have high smoke point are less susceptible to break during deep-frying or re- frying and can be utilized. Some of the oils with their high smoke point are mentioned in Table 4 below. At last, the main focus has to be on- "Eat healthy, live happy".

\begin{tabular}{|l|c|}
\hline Type of oil & $\begin{array}{c}\text { Approximate smoke } \\
\text { point }\end{array}$ \\
\hline Peanut, Safflower, Soybean & $450^{\circ} \mathrm{F}$ \\
\hline Grapeseed & $445^{\circ} \mathrm{F}$ \\
\hline Canola & $435^{\circ} \mathrm{F}$ \\
\hline Corn, Olive, Sesame seed, Sunflower & $410^{\circ} \mathrm{F}$ \\
\hline
\end{tabular}

Table 4: Smoke point of oils [8].

\section{Bibliography}

1. http://chemwiki.ucdavis.edu/Textbook_Maps/General_ Chemistry_Textbook_Maps/Map\%3A_The_Basics_of_GOB_ Chemistry_(Ball_et_al.)/17\%3A_Lipids/17.2_Fats_and_Oils

2. http://scifun.chem.wisc.edu/chemweek/pdf/fats\&oils.pdf

3. http://www.nutristrategy.com/fatsoils.htm

4. http://www.scielo.org.ve/pdf/alan/v63n1/art01.pdf

5. https://books.google.co.in/books?id=YgHLBAAAQBAJ\&pg= PA66\&lpg=PA66\&dq=permissible+free+fatty+acids ++ in + oil \&source=bl\&ots=GqhrAulchj\&sig=WKVBPfVFcWCwgbSZgS4 1QKfB-48\&hl=en\&sa=X\&ved=0ahUKEwjgkoeQ89HMAhUIp Y8KHeDZCQQQ6AEIMTAD\#v=onepage \&q=permissible $\% 20$ free $\% 20$ fatty $\% 20$ acids $\% 20 \% 20 \mathrm{in} \% 20$ oil\&f=false

6. http://www.scielo.org.ve/pdf/alan/v63n1/art01.pdf

7. http://ajfand.net/Volume14/No6/Diop13315.pdf

8. http://www.fsis.usda.gov/wps/wcm/connect/65f762d0e4d 0-4278-b5cb-2836854a3eda/Deep_Fat_Frying. pdf?MOD=AJPERES

Volume 3 Issue 6 June 2019

(C) All rights are reserved by Parul Thapar. 